\title{
EFFICACY OF MICRODOSES POTENTIZED HOMEOPATHIC DRUG, ARSENICUM ALBUM INDUCED BY ARSENIC TRIOXIDE IN ZEBRAFISH (DANIO RERIO)-A FTIR STUDY IN GILLS
}

\author{
VIJAY VELU, RAMESH UTHANDAKALAIPANDIAN* \\ Department of Molecular Biology, School of Biological Sciences, Madurai Kamaraj University, Madurai, Tamil Nadu \\ Email: urameshmku@gmail.com
}

Received: 22 Sep 2016 Revised and Accepted: 27 Oct 2016

\begin{abstract}
Objective: Arsenic, one of the major natural as well as anthropogenic pollutant produces biochemical changes in the organs of animals due to its potential toxicity. Arsenic is toxic to fish and may be taken through gills and skin. In the current work, arsenic trioxide-treated fishes were prescribed with potentized homoeopathic drug, ars alb 30C, and ars alb 200C. The biochemical contents in exposed gill tissues of zebra fish (Danio
\end{abstract} rerio) were analysed using Fourier transform infrared spectroscopy (FTIR).

Methods: The acclimatised fish were treated with arsenic trioxide and $\mathrm{LC}_{50}$ was calculated. Along with arsenic trioxide, the homoeopathic drug ars alb 30C and ars alb 200C were given three drops per litre. After a period of 7 and $14 \mathrm{~d}$, the gills of exposed fish were dissected. The samples were lyophilized and analysed in FTIR.

Results: In arsenic exposed fish, the amine N-H stretch was different when compared to the control and the treated different potencies of ars alb $30 \mathrm{C}$ and $200 \mathrm{C}$ respectively at 7days. Whereas at $14 \mathrm{~d}$ the arsenic exposed fish the amine $\mathrm{N}-\mathrm{H}$ stretch was drastically reduced. Notably, in treating different potencies of ars alb 30C and 200C, the amine N-H stretch was increased.

Conclusion: It was found that the higher the potency that is ars alb 200C was more effective against Arsenic toxicity. It shows higher dilution may be efficacious.

Keywords: Arsenic trioxide, Ars alb, Gills, FTIR

(C) 2017 The Authors. Published by Innovare Academic Sciences Pvt Ltd. This is an open access article under the CC BY license (http://creativecommons.org/licenses/by/4. 0/) DOI: http://dx.doi.org/10.22159/ijpps.2017v9i1.15314

\section{INTRODUCTION}

Arsenic one of the major contaminant in groundwater, possibly cause many sufferings in humans as well as organisms in water [1]. In West Bengal, India, the amount of arsenic, was getting discharged progressively, crumbled in water, with aquatic and soil sediment [2]. Absorption of arsenic is being controlled by a mixture of input and removal mechanisms happened in the aquatic environment. Accumulation of arsenic in the physical system leads to physiological and biochemical disorders. An aquatic ecosystem is a disparate association of organisms and biotic factors, which are interrelated, even the micro-modifications in the environment can change the nature and conduct of the organisms. Freshwater fish constitute one of the major origins of cheap nutrition for human beings. Biochemical composition of proteins, carbohydrates, free amino acids, lipids and mineral contents are the important nutritional values of fish [3]. The global yield of farmed fish more than doubled in value over the past decade. The fish developed from farming activities currently account for over one after parting of all fish directly consumed by humans. As the human population continues to rise, the reliance on farmed fish production as an important source of protein will also increase [4]. The consequence of inorganic arsenic species might result in a larger number of adverse health effects to the cosmopolitan public. Thus, it is important to evaluate the inorganic arsenic levels of farmed seafood in arsenicpolluted fields [5]. These answers indicate that the dwellers of the arsenic polluted region are being subjected to moderately elevated arsenic exposure through the use of tilapia and shrimp raised in aquaculture ponds.

The bulk of toxic stuff initiates biochemical alterations like inhibition of the enzyme system, the amendment in the level of enzyme and individual alteration in the permeability of biological membranes [6]. The rate of elimination of arsenic became more composite because of the poor people health and hygiene status and the relatively low affordability of the greater majority of the population surviving in contaminated zones. And for the lack of awareness of the potential effects of arsenic poisoning in most of them. Mainly with such an environment, the initial object was to find out suitable antagonists of arsenic poisoning, which should be easily executable, in force in less quantity and low price.

Earlier certain studies were getting on with mice a potentized homoeopathic drug, ars alb 30C and it presents a promising result [7]. The biomedical technique Fourier Transform Infrared Spectroscopy (FTIR) is unitary of the techniques that can potentially discover a wealth of qualitative and quantitative information about a given biological sample. Tissue components, including membranes, proteins, nucleic acids and polysaccharide compounds can be evaluated by FTIR spectroscopy. This indicates that this technique is valuable for analysing complicated biological materials, including tissues, body fluids or cell cultures. The transformation in the top positions, bandwidth and the saturation of the stripes, all give valuable structural and operational information which may have diagnostic value for biological systems. Thus, it seemed exciting to apply FTIR spectroscopy to monitor disease induced and arsenic toxicity induced biochemical changes occurring in any living organism and to evaluate the quantitative and semi-quantitative effects of various factors on biological structures.

\section{MATERIALS AND METHODS}

Test species

Zebrafish (D. rerio) adults (length: $4 \pm 0.2$; weight: $2 \pm 0.3$ ) total of 100 was obtained from Muthupandi fish farm, Kadachanenthal, Madurai District, Tamil Nadu, India. It was acclimatised in laboratory conditions in glass tanks for a minimal period of $14 \mathrm{~d}$. It was maintained under temperature conditions of $25 \pm 2{ }^{\circ} \mathrm{C}, 12 \mathrm{~h} / 12 \mathrm{~h}$ light/dark cycle. At the time of the experiment, the fish were fed with artemia.

\section{Test chemicals}

Arsenic trioxide was purchased from Karnataka fine chemicals and arsenicum album was purchased from Dr Reckweg, Germany. 


\section{Lethality studies}

The $\mathrm{LC}_{50}$ values for arsenic trioxide were determined by using the arithmetic method of Sprague [8] and were set up to be $400 \mu \mathrm{M}$. Fishes were maintained in a glass tank of $20 \mathrm{~L}$ capacity along with continuous air supply throughout the experiment. The physicochemical characteristics of test water were maintained accordingly by APHA [9] standards, such as $\mathrm{pH}$ (7-7.2), total alkalinity $(125-131 \mathrm{mEq} / \mathrm{l})$, total hardness $\left(200-205 \mathrm{mg} / \mathrm{l}\right.$ as $\left.\mathrm{CaCO}_{3}\right)$, calcium (50-56 mg/l), magnesium $(18-22 \mathrm{mg} / \mathrm{l})$ and DO (89-90 $\mathrm{mg} / \mathrm{l}$ ). During the experimental period, the water was changed every day and the fecal materials were removed. Throughout the experiment, physicochemical parameters were determined.

\section{Experimental study}

The observational work was conducted to examine the effect of homoeopathic drug ars alb by the method of Sparks [10]. The fish were acclimatized and grouped as follows in triplicate containing 10 fishes in each group and it was divided into Group I-VII such as,

Group I: positive control which is $\mathrm{As}_{2} \mathrm{O}_{3}$ intoxicated group, Group II: $\mathrm{As}_{2} \mathrm{O}_{3}$ intoxicated ars alb 200C group, Group III: $\mathrm{As}_{2} \mathrm{O}_{3}$ intoxicated ars alb 30C group, Group IV: act as alcohol control since ethyl alcohol was considered as the vehicle of the homeopathic remedies, Group V: fish treated with ars alb $200 \mathrm{C}$ alone, Group VI: fish treated with ars alb 30C alone and Group VII: negative Control, it consists of healthy fish not treated with arsenic.

Three drops per litre of ars alb 30C and ars alb 200C were given thrice a day to $\mathrm{As}_{2} \mathrm{O}_{3}$ intoxicated Group. The fishes were exposed to arsenic trioxide for $14 \mathrm{~d}$ (acute). After the experimental period was over, the gill tissues of the exposed fishes were removed for further process.

\section{Sample preparation}

The collected gill tissues were dried by lyophilizer (Martin Christ, Deutschland) for $12 \mathrm{~h}$. After drying the samples were ground to obtain the powder form of the gill, following which it was mixed in a ratio of 1:100 with dried potassium bromide and 5 tons of pressure was given for 5 min to make a transparent $\mathrm{KBr}$ disc.

\section{Spectroscopic measurement}

The FTIR spectroscopic measurement was done using Spectrum $\mathrm{Two}^{\mathrm{TM}}$ from PerkinElmer. Wavelength ranging from 4000 to $400 \mathrm{~cm}^{-}$ ${ }^{1}$ was covered by this FTIR spectrometer. The intensity peak absorbed was calculated with ORIGIN 8.0 software.

\section{RESULTS}

The present study deals with the effect of ars alb intoxicated with arsenic and the changes in biochemical contents of $D$. rerio gills using FTIR technique. The average FTIR Spectra obtained from control, and the other groups specifically. $\mathrm{As}_{2} \mathrm{O}_{3}$ intoxicated, $\mathrm{As}_{2} \mathrm{O}_{3}$ intoxicated ars alb 200C, $\mathrm{As}_{2} \mathrm{O}_{3}$ intoxicated ars alb 30C, ethyl alcohol, ars alb 200C and ars alb 30C. Obtained peak region and spectra are represented in fig. 1 and 2.

The structural, as well as functional information value, were conveniently obtained by the shifts in peak position [11]. Important functional groups such as proteins, lipids, ester, amide and nucleic acids can be validated via FTIR.

The spectrum consists of several bands arising from the functional groups belonging to the vibrational assignments of FTIR spectra for control, $\mathrm{As}_{2} \mathrm{O}_{3}$ Intoxicated, $\mathrm{As}_{2} \mathrm{O}_{3}$ intoxicated ars alb 200C, $\mathrm{As}_{2} \mathrm{O}_{3}$ intoxicated ars alb 30C, ethyl alcohol, ars alb 200C and ars alb 30C fish tissue samples in the $4000-400 \mathrm{~cm}^{-1}$ for $7 \mathrm{~d}$ and $14 \mathrm{~d}$ respectively were presented in table 1 and table 2 .

In fig. 1 the spectrum of control shows the band of $\sim 3401 \mathrm{~cm}^{-1}$ which has the vibrational assignment of an amine $\mathrm{N}-\mathrm{H}$ stretch. $1 \mathrm{~g}$ which is arsenic intoxicated showed decreased $\mathrm{N}-\mathrm{H}$ stretching bands $\sim 3287$ $\mathrm{cm}^{-1}$ of proteins, whereas in the case of $2 \mathrm{~g} \mathrm{As}_{2} \mathrm{O}_{3}+$ ars alb $200 \mathrm{C}$ the rate of peak shift $\sim 3293 \mathrm{~cm}^{-1}$ was slightly varied in comparing to arsenic intoxicated. In the case of $3 \mathrm{~g} \mathrm{As}_{2} \mathrm{O}_{3}+\mathrm{ars}$ alb $30 \mathrm{C}$, the rate of peak shift was similar to arsenic intoxicated since it contains low dilution of arsenic trioxide. Its shows at $7 \mathrm{~d}$ of treatment there is an effective change in vibrational assignment.

The absorptions in this area are dominated by the amide A of proteins and are due to stretching vibrations of $\mathrm{N}-\mathrm{H}$ groups in the peptide chains of the protein macromolecules and intermolecular $\mathrm{H}$ bonding. The position of amide A band in the spectra indicates that the $\mathrm{N}-\mathrm{H}$ groups are associated because a maximum of the absorption bands of free $\mathrm{N}-\mathrm{H}$ vibrations in protein macromolecules are located at $\sim 3480-3450 \mathrm{~cm}^{-1}$.

In fig. 2 the spectrum of control shows the band of $\sim 3401 \mathrm{~cm}^{-1}$ which has the vibrational assignment of an amine $\mathrm{N}-\mathrm{H}$ stretch. 2a1g which is arsenic intoxicated showed more decreased $\mathrm{N}-\mathrm{H}$ stretching bands $\sim 3277 \mathrm{~cm}^{-1}$ of proteins, whereas in the case of $2 \mathrm{a} 2 \mathrm{~g} \mathrm{As} \mathrm{O}_{3}+\mathrm{ars}$ alb 200C the rate of peak shift $\sim 3304 \mathrm{~cm}^{-1}$ was slightly varied in compared to arsenic intoxicated. In the case of $2 \mathrm{a} 3 \mathrm{~g} \mathrm{As}_{2} \mathrm{O}_{3}+\mathrm{ars}$ alb $30 \mathrm{C}$ the rate of peak shift $\sim 3282 \mathrm{~cm}^{-1}$ was similar to arsenic intoxicated since it contains low dilution of arsenic trioxide. Its shows at $7 \mathrm{~d}$ of treatment there is an effectual change in vibrational assignment.

In fig. 1 the spectrum of control shows the band of $\sim 2922 \mathrm{~cm}^{-1}$ and $\sim 2853 \mathrm{~cm}^{-1}$ which have the vibrational assignment of an alkyl C-H stretch. $1 \mathrm{~g}$ which is arsenic intoxicated showed decreased $\mathrm{CH}_{3}$ asymmetric stretching: mainly lipids bands $\sim 2920 \mathrm{~cm}^{-1}$, whereas in the case of $2 \mathrm{~g} \mathrm{As}_{2} \mathrm{O}_{3}+\mathrm{ars}$ alb $200 \mathrm{C}$ and $3 \mathrm{~g} \mathrm{As}_{2} \mathrm{O}_{3}+$ ars alb $30 \mathrm{C}$ the rate of peak shift $\sim 2923 \mathrm{~cm}^{-1}$ remains same.

In fig. 2 the spectrum of control shows the band of $\sim 2922 \mathrm{~cm}^{-1}$ and $\sim 2853 \mathrm{~cm}^{-1}$ which have the vibrational assignment of an alkyl C-H stretch.

2a1g which is arsenic intoxicated showed decreased $\mathrm{CH}_{3}$ asymmetric stretching: mainly lipids bands $\sim 2920 \mathrm{~cm}^{-1}$ whereas in the case of 2a2g As${ }_{2} \mathrm{O}_{3}$ ars alb $200 \mathrm{C}_{2}$ symmetric stretching: mainly lipids showed no peak value and $2 \mathrm{a} 3 \mathrm{~g} \mathrm{As} \mathrm{O}_{3}$ ars alb $30 \mathrm{C}$ the rate of peak shift $\sim 2851 \mathrm{~cm}^{-1}$ remains closer to the central peak.

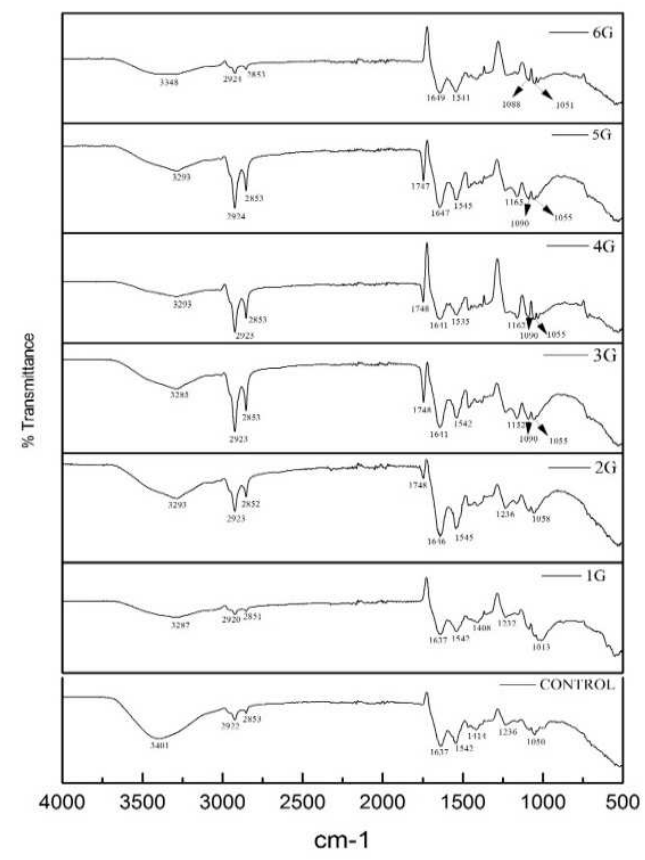

Fig. 1: FTIR spectra vibrational assignment of $1 \mathrm{~g}-\mathrm{As}_{2} \mathrm{O}_{3}$ intoxicated, $2 \mathrm{~g}-\mathrm{As}_{2} \mathrm{O}_{3}$ intoxicated ars alb 200C, $3 \mathrm{~g}-\mathrm{As}_{2} \mathrm{O}_{3}$ intoxicated ars alb 30C, 4g-ethyl alcohol, 5g-ars alb 200C and $6 \mathrm{~g}$-ars alb $30 \mathrm{C}$ treated gills of $D$. rerio

In fig. 1 the spectrum of control shows the band of $\sim 1637 \mathrm{~cm}^{-1}$ which has the vibrational assignment of amide $\mathrm{C}=0$ Stretch.

$1 \mathrm{~g}$ which is arsenic intoxicated showed the same band as a control but later at the $14 \mathrm{~d}$; the band was stretched $\sim 1647 \mathrm{~cm}^{-1}$ (fig. 2) of 
amide II: $\mathrm{C}=\mathrm{O}$ stretching of proteins. whereas in the case of $2 \mathrm{~g}$ $\mathrm{As}_{2} \mathrm{O}_{3}+$ ars alb 200C the rate of peak shift increased to the wavelength of $\sim 1646 \mathrm{~cm}^{-1}$ (fig. 1) later on the band was similar to control $\sim 1638 \mathrm{~cm}^{-1}$ (fig. 2). In $3 \mathrm{~g} \mathrm{As}_{2} \mathrm{O}_{3}+$ ars alb $30 \mathrm{C}$ the rate of peak shift was in increased condition arsenic intoxicated since it contains low dilution of arsenic trioxide.

Table 1: FTIR spectra vibrational assignment of $1 \mathrm{~g}-\mathrm{As}_{2} \mathrm{O}_{3}$ intoxicated, $2 \mathrm{~g}-\mathrm{As}_{2} \mathrm{O}_{3}$ intoxicated ars alb $200 \mathrm{C}, 3 \mathrm{~g}-\mathrm{As} \mathrm{S}_{2} \mathrm{O}_{3}$ intoxicated ars alb $30 \mathrm{C}$, 4g-ethyl alcohol, 5g-ars alb 200C and 6g-ars alb 30C treated gills of $D$. rerio

\begin{tabular}{lllllllll}
\hline S. No. & \multicolumn{2}{l}{ Peak position } & & & & & Vibrational assignments \\
\cline { 2 - 7 } & Control & 2a1g & $\mathbf{2 a 2 g}$ & $\mathbf{2 a 3 g}$ & $\mathbf{2 a 4 g}$ & $\mathbf{2 a 5 g}$ & $\mathbf{2 a 6 g}$ & \\
\hline 1 & 3401 & 3277 & 3304 & 3282 & 3287 & 3299 & 3299 & amine N-H stretch \\
2 & 2922 & 2924 & 2915 & 2922 & 2924 & 2924 & 2914 & $\mathrm{CH}_{3}$ asymmetric stretching: mainly lipids \\
3 & 2853 & - & - & 2851 & 2853 & 2853 & - & $\mathrm{CH}_{2}$ symmetric stretching: mainly lipids \\
4 & 1637 & 1647 & 1638 & 1650 & 1644 & 1646 & 1644 & amide II: C=O stretching of proteins \\
5 & 1542 & 1539 & 1542 & 1547 & 1539 & 1545 & 1549 & amide II: N-H bending and C-N stretching of proteins \\
6 & 1414 & 1410 & 1408 & 1410 & 1410 & 1404 & 1407 & N-H bending: amino acids \\
7 & 1236 & 1233 & 1231 & 1234 & 1234 & 1234 & 1231 & PO asymmetric stretching: mainly phospholipids \\
8 & 1050 & 1056 & 1049 & 1051 & 1088 & 1057 & 1047 & C-C stretching of lipids \\
\hline
\end{tabular}

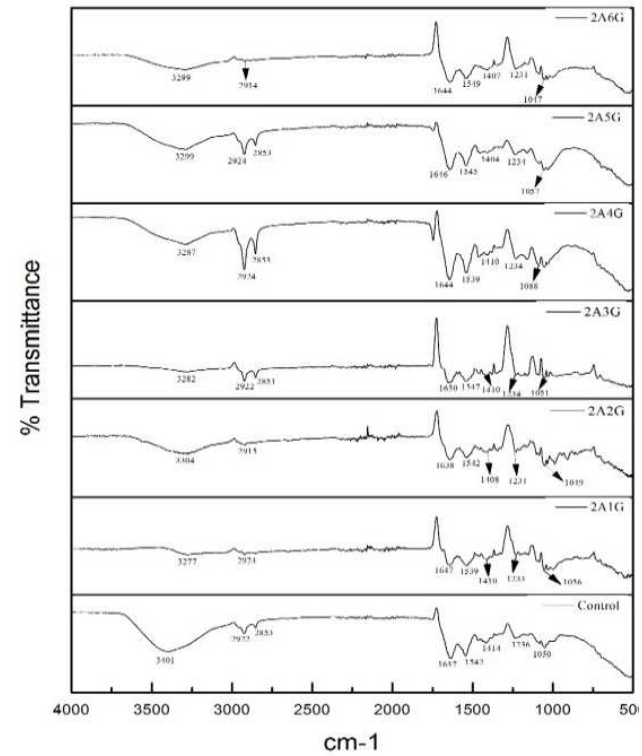

Fig. 2: FTIR spectra vibrational assignment of control 2a1g$\mathrm{As}_{2} \mathrm{O}_{3}$ intoxicated, $2 \mathrm{a} 2 \mathrm{~g}-\mathrm{As}_{2} \mathrm{O}_{3}$ intoxicated ars alb 200C, 2a3g$\mathrm{As}_{2} \mathrm{O}_{3}$ intoxicated ars alb $30 \mathrm{C}, 2 \mathrm{a} 4 \mathrm{~g}-\mathrm{ethyl}$ alcohol, 2a5g-ars alb $200 \mathrm{C}$ and $2 \mathrm{a} 6 \mathrm{~g}$-ars alb $30 \mathrm{C}$ treated gills of $D$. rerio

In fig. 1 the spectrum of control shows the band of $\sim 1542 \mathrm{~cm}^{-1}$ which has the vibrational assignment of amide II: N-H bending and C-N stretching of proteins. $1 \mathrm{~g}$ which is arsenic intoxicated showed same band as control, but later at $14 \mathrm{~d}$ the band was decreased to $\sim 1539$ $\mathrm{cm}^{-1}$ (fig. 2) of proteins, whereas in case of $2 \mathrm{~g} \mathrm{As} \mathrm{O}_{3}+$ ars alb $200 \mathrm{C}$ the rate of peak shift increased to $\sim 1545 \mathrm{~cm}^{-1}$ (fig. 1) later on the band was similar to control $\sim 1542 \mathrm{~cm}^{-1}$ (fig. 2). In $3 \mathrm{~g} \mathrm{As}_{2} \mathrm{O}_{3}+$ ars alb $30 \mathrm{C}$ showed the same band as a control, but later at $14 \mathrm{~d}$ the band was increased to $\sim 1547 \mathrm{~cm}^{-1}$ (fig. 2) of proteins.

In fig. 1 the spectrum of control shows the band of $\sim 1414 \mathrm{~cm}^{-1}$ which has the vibrational assignment of $\mathrm{N}-\mathrm{H}$ bending: amino acids. $1 \mathrm{~g}$ which is arsenic intoxicated showed decreased band of $\sim 1408 \mathrm{~cm}^{-1}$, but later at $14 \mathrm{~d}$ the band was increased to wavelength $\sim 1410 \mathrm{~cm}^{-1}$ (fig. 2), whereas in case of $2 \mathrm{~g} \mathrm{As}_{2} \mathrm{O}_{3}+$ ars alb 200C the rate of peak shift decreased to $\sim 1545 \mathrm{~cm}^{-1}$ (fig. 1) later on the band was increased to $\sim 1408 \mathrm{~cm}^{-1}$ (fig. 2). In $3 \mathrm{~g} \mathrm{As}_{2} \mathrm{O}_{3}+$ ars alb $30 \mathrm{C}$ showed no stretched band at $7 \mathrm{~d}$ and but later at $14 \mathrm{~d}$ the band was increased to $\sim 1410 \mathrm{~cm}^{-1}$ (fig. 2).

In fig. 1 the spectrum of control shows the band of $\sim 1236 \mathrm{~cm}^{-1}$ which has the vibrational assignment of $\mathrm{PO}_{2}$ asymmetric stretching: mainly phospholipids.

$1 \mathrm{~g}$ which is arsenic intoxicated showed decreased band of $\sim 1232$ $\mathrm{cm}^{-1}$ on $7 \mathrm{~d}$, but at $14 \mathrm{~d}$ the band was $\sim 1233 \mathrm{~cm}^{-1}$ (fig. 2), whereas in case of $2 \mathrm{~g} \mathrm{As}_{2} \mathrm{O}_{3}+$ ars alb 200C the rate of peak shift decreased to $\sim 1236 \mathrm{~cm}^{-1}$ (fig. 1) later on the band was decreased to $\sim 1231 \mathrm{~cm}$ ${ }_{1}^{1}$ (fig. 2). In $3 \mathrm{~g} \mathrm{As}_{2} \mathrm{O}_{3}+$ ars alb $30 \mathrm{C}$ showed stretched band was found to be $\sim 1235 \mathrm{~cm}^{-1}$ at $7 \mathrm{~d}$ and but later at $14 \mathrm{~d}$ the band as reduced to $\sim 1234 \mathrm{~cm}^{-1}$ (fig. 2).

No stretching band was available at ethyl alcohol and homoeopathic medicine ars alb 30C alone on the $7 \mathrm{~d}$ and the stretching peaks were observed at $14 \mathrm{~d}$ found to be decreased.

In fig. 1 the spectrum of control shows the band of $\sim 1050 \mathrm{~cm}^{-1}$ which have the vibrational assignment of $\mathrm{C}-\mathrm{C}$ stretching of lipids.

$1 \mathrm{~g}$ which is arsenic intoxicated showed decreased band of $\sim 1013 \mathrm{~cm}$ ${ }^{1}$ on $7 \mathrm{~d}$ but, at $14 \mathrm{~d}$ the band was $\sim 1056 \mathrm{~cm}^{-1}$. Whereas in the case of $2 \mathrm{~g} \mathrm{As}_{2} \mathrm{O}_{3}+$ ars alb $200 \mathrm{C}$ the rate of peak shift was $\sim 1058 \mathrm{~cm}^{-1}$ (fig. 1) later on the band was decreased to $\sim 1049 \mathrm{~cm}^{-1}$ (fig. 2). In $3 g \mathrm{As}_{2} \mathrm{O}_{3+}$ ars alb 30C showed stretched band was found to be $\sim 1055 \mathrm{~cm}^{-1}$ at $7 \mathrm{~d}$ and but later at $14 \mathrm{~d}$ the band was reduced to $\sim 1051 \mathrm{~cm}^{-1}$ (fig. 2).

Table 2: FTIR spectra vibrational assignment of $2 \mathrm{a} 1 \mathrm{~g}-\mathrm{As}_{2} \mathrm{O}_{3}$ intoxicated, $2 \mathrm{a} 2 \mathrm{~g}-\mathrm{As}_{2} \mathrm{O}_{3}$ intoxicated ars alb 200C, $2 \mathrm{a} 3 \mathrm{~g}$-As $\mathrm{O}_{3}$ intoxicated ars alb 30C, 2a4g-ethyl alcohol, 2a5g-ars alb 200C and 2a6g-ars alb 30C treated gills of D. rerio

\begin{tabular}{lllllllll}
\hline \multirow{2}{*}{ S. No. } & \multicolumn{2}{l}{ Peak position } & & & & & Vibrational assignments \\
\cline { 2 - 7 } & Control & $\mathbf{1 g}$ & $\mathbf{2 g}$ & $\mathbf{3 g}$ & $\mathbf{4 g}$ & $\mathbf{5 g}$ & $\mathbf{6 g}$ & \\
\hline 1 & 3401 & 3287 & 3293 & 3285 & 3293 & 3293 & 3348 & amine N-H stretch \\
2 & 2922 & 2920 & 2923 & 2923 & 2923 & 2924 & 2924 & $\mathrm{CH}_{3}$ asymmetric stretching: mainly lipids \\
3 & 2853 & 2851 & 2852 & 2853 & 2853 & 2853 & 2853 & $\mathrm{CH}_{2}$ symmetric stretching: mainly lipids \\
4 & 1637 & 1637 & 1646 & 1641 & 1641 & 1647 & 1649 & amide C=O stretch \\
5 & 1542 & 1542 & 1545 & 1542 & 1542 & 1545 & 1541 & amide II: N-H bending and C-N stretching of proteins \\
6 & 1414 & 1408 & 1404 & - & - & - & - & N=O bend \\
7 & - & - & - & 1152 & 1162 & 1165 & - & C-N amines \\
8 & 1236 & 1232 & 1236 & 1235 & 1235 & - & - & PO asymmetric stretching: mainly phospholipids \\
9 & 1050 & 1013 & 1058 & 1055 & 1055 & 1055 & 1051 & C-C stretching of lipids \\
\hline
\end{tabular}

Ethyl alcohol, $4 \mathrm{~g}$ and 2a4g for 7 and $14 \mathrm{~d}$ respectively, shows no significance changes in the position but the stretching of the peak was higher when compared to ars alb. Likewise when ars alb 200C (5g and 2a5g) and ars alb 30C (6g and 2a6g) alone given for 7 and $14 \mathrm{~d}$ respectively, shows the effect similar to arsenic intoxicated. Hence, it considered that higher the dilution was more effective. 


\section{DISCUSSION}

This FTIR study was based upon the toxicology effect of arsenic in fish gills. A study on biochemical changes in the kidney of Labeo rohita intoxicated with arsenic found that FTIR study can be applied for toxicology [12]. As well a related study of ars alb 30C and ars alb 200 was said to be more effective [13]. Further studies were carried out that the ars alb contains ultra high dilution of Arsenic trioxide was re-equilibrate upregulated genes at the time of oxidate stress by brought back expression levels [14].

Since arsenic was treat along with the water, there might be an alteration in the protein content of the fish, and there seems the intensity was decreased in amide bands [15]. Arsenic is a kind of metalloid, and it has the capability to have a strong interaction with thiol groups, thiol residues in proteins, regarding these functions it affects the structure of the molecules present in the gills [16].

Cakmak and his colleagues [17] studied the effect of nonylphenol, found the structural analysis and functional proteins based upon FTIR study. Based his way the investigation was applied to arsenic and alternative medicine on arsenic toxicity i. e Arsenicum album. Furthermore, by this examination on FTIR-a time of $14 \mathrm{~d}$ concentrate on it was found that the measure of protein and lipid content in the gill was radically changed in a brief time of days when contrasted with arsenic intoxicated, control and ars alb habituated.

\section{CONCLUSION}

Arsenicum album was unrevealed as a major homeopathic medicine against arsenic poisoning. By this investigation, it was concluded that the FTIR study on gills shows the alteration due to arsenic intoxication. In contrast, when the fish was treated with a higher dilution of arsenic that is ars alb 200C shows the most promising result, whereas ars alb 200C shows compatible results when compared to ars alb 200C. Since arsenic intoxication shows variable effects in biochemical constituents of gills, it is essential to finding a valuable resource to treat. In such condition, homeopathic treatment may be considered as an alternate means to handle.

\section{ACKNOWLEDGEMENT}

The author would like to thank DST-INSPIRE Fellowship Scheme for the funding and UGC-NRCBS for providing instrumentation facility.

\section{CONFLICT OF INTERESTS}

Declared none

\section{REFERENCES}

1. Chowdhury UK, Rahman MM, Mondal BK, Paul K, Lodh D, Biswas BK, et al. Groundwater arsenic contamination and human suffering in West Bengal, India and Bangladesh. Environ Sci 2001;8:393-415.

2. Cullen WR, Reimer KJ. Arsenic speciation in the environment. Chem Rev 1989;89:713-764.
3. Naylor RL, Goldburg RJ, Primavera JH, Kautsky N, Beveridge MCM, Clay J, et al. Effect of aquaculture on world fish supplies. Nature 2000;405:1017-24.

4. Huang YK, Lin KH, Chen HW, Chang CC, Liu CW, Yang MH, et al. Arsenic species contents at aquaculture farm and in farmed mouthbreeder (Oreochromis mossambicus) in blackfoot disease hyperendemic areas. Food Chem Toxicol 2003;41:1491-500.

5. Kar S, Maity JP, Jean JS, Liu CC, Liu CW, Bundschuh J, et al. Health risks for human intake of aquacultural fish: arsenic bioaccumulation and contamination. J Environ Sci Health, Part A: Toxic/Hazard. Subst Environ Eng 2011;46:1266-73.

6. Pillay TVR. Aquaculture and the environment. Oxford, UK; Fishing News Book; 1992. p. 189.

7. Litchfield JT, Wilcoxon F. A simplified method of evaluating doseeffect experiments. J Pharmacol Exp Ther 1949;96:99-113.

8. Sprague JB. Measurement of pollutant toxicity to fish. I. Bioassay methods for acute toxicity. Water Res 1979;3:793-821.

9. APHA. Standard methods for the examination of water and wastewater. $21^{\text {st }}$ ed. Published by APHA, AWWA, WEF, Washington DC; 2005.

10. Sparks T. Statistics in ecotoxicology. Wiley, New York; 2000. p. 320.

11. Cakmak G, Togan I, Uguz C, Severcan F. FTIR spectroscopic analysis of rainbow trout liver exposed to nonylphenol. Appl Spectrosc 2003;57:835-41.

12. Palaniappan PL, Vijayasundaram V. Arsenic-induced biochemical changes in Labeo rohita kidney: an FTIR study. Spectrosc Lett 2009;42:213-8.

13. Mallick P, Mallick JC, Guha B. Ameliorating effect of microdoses of a potentized homoeopathic drug, arsenicum album, on arsenic-induced toxicity in mice. BMC Complementary Altern Med 2003;3:7.

14. Samuel S, Kathirvel R, Jayavelu T, Chinnakkannu P. Protein oxidative damage in arsenic-induced rat brain: influence of DLa-lipoic acid. Toxicol Lett 2005;155:27-34.

15. Ilaria M, Lucietta B, Valeria B, Sara B, Grazia T, Giovanni B, et al. Transcriptome profiling of wheat seedlings following treatment with ultrahigh diluted arsenic trioxide. J Evid Based Complementary Altern Med 2014:1-15. Doi:10.1155/2014/851263.

16. Webb JL. Enzymes and metabolic inhibitors. Vol. III. Academic: New York; 1996. p. 595-793.

17. Cakmak G, Togan I, Severcan F. 17-Estradiol induced compositional, structural and functional changes in rainbow trout liver, revealed by FTIR spectroscopy: a comparative study with nonylphenol. Aquat Toxicol 2006;77:53-63.

\section{How to cite this article}

- Vijay Velu, Ramesh Uthandakalaipandian. Efficacy of microdoses potentized homeopathic drug, arsenicum album induced by arsenic trioxide in zebrafish (Danio rerio)-a ftir study in gills. Int J Pharm Pharm Sci 2017;9(1):48-51. 